\title{
A CSÖKKENTETT ALKOHOLTARTALMÚ ÉS ALKOHOLMENTESÍTETT BOROK FOGYASZTÓI MEGÍTÉLÉSE ÉS PERSPEKTÍVÁI (MAGYARORSZÁGON)
}

\author{
- भी० -

\section{CONSUMER PERCEPTION AND PERSPECTIVES OF WINES WITH REDUCED ALCOHOL CONTENT AND NON-ALCOHOLIC WINES (IN HUNGARY)} \\ TOTTH, GEDEON \\ ZARÁNDNÉ VÁMOSI, KORNÉLIA \\ - \\ Budapesti Gazdasági Egyetem Külkereskedelmi Kar, Marketing Tanszék \\ (Marketing Department, Faculty of International Management and Business Budapest Business School) \\ H-1165, Budapest, Diósy Lajos u. 22-24. \\ e-mail: Totth.Gedeon@uni-bge.hu
}

\begin{abstract}
si
Significant changes have taken place in the international wine supply in recent times and the volume of non-alcoholic wines and the ones with reduced alcohol content and the consumer interest in them have increased as well. The latter is caused by changing consumer habits, like the development of health awareness and the fact that healthier eating is becoming more common. The present study provides a brief overview of some characteristics of the demand for non-alcoholic and reduced-alcohol wines, consumer perceptions, and the effects of alcohol on health. Based on some Hungarian wine consumer behavior research, this research examines the reasons behind the refusal to drink wine, and consumer opinions on the relationship between wine consumption and alcoholism. The revealed phenomena and the preferences and attitudes influencing them intend to prepare the basis for a research examining the domestic possibilities and potentials of non-alcoholic and reduced-alcohol wines.
\end{abstract}

KuLCSSZAVAK: csökkentett alkoholtartalom, alkoholmentesített, bor, fogyasztói magatartás

JEL-KóDOK (JEL CODES): M31

DOI: https://doi.org/10.20494/TM/8/2/1

\section{BEVEZETÉS - INTRODUCTION}

A borfogyasztási szokásokban az elmúlt évtizedekben figyelemreméltó változásoknak lehettünk tanúi. Módosultak a szokások, és az elvárásokban is számottevő változások következtek be, megnövekedett az igény az olyan könnyebb és alacsonyabb alkoholtartalmú borok iránt,
KEYwORDS: reduced alcohol content, non-alcoholic, wine, consumer behavior

amelyek egyrészről jobban megfelelnek az új fogyasztási alkalmaknak (a bor egyre inkább a szórakozások ital kísérője), másrészről a korszerű táplálkozási szokásoknak és az alkoholfogyasztást kerülő élethelyzetek mind gyakoribbá válásának (SIDLOVITS, 2019). A világ számos pontján egyre határozottabb lépéseket tesznek az alkoholfogyasztás visszaszorítására a túlzott 
fogyasztásnak az egészségre gyakorolt káros hatása miatt. Magyarország 2016 óta tagja a Wine in Moderation nemzetközi programnak, mely a mérsékelt borfogyasztás előmozdítását tűzte ki zászlajára. A nemzetközi mozgalomnak az intenzív edukációs tevékenysége is erősítette az alacsonyabb alkoholtartalmú borok iránti igényt. A legfontosabb alkoholtartalmú helyettesítő termékekkel (sör, égetett szeszesitalok) való verseny is innovatív megoldásokra késztette a borágazatot, mindkét előbb említett helyettesítő termék kategóriában, a sörnél ráadásul közel fél évszázada megjelentek a piacon a csökkentett alkoholtartalmú, illetve az alkoholmentesített termékek. Mindez a borágazatot is arra késztette, hogy ebbe az irányba nyitva, megpróbálja kínálatába illeszteni a csökkentett alkoholtartalmú, illetve alkoholmentesített termékeket. Segítette a bortermelőket a már említett fogyasztói magatartásban bekövetkezett változásokon túl a globális felmelegedés, mely a szőlő korábbi érésével, és ebből következően cukortartalmának a növekedésével járt. A korábbi szüret egyrészről károsan hathat a bor minőségére, másrészről a magas cukortartalom magasabb alkoholtartalmat eredményez. Ezek a tényezők indították a francia INRA kutatóit olyan módszer kidolgozására, mellyel a bor alkoholtartalma csökkenthető (TRADE MAGAZIN, 2012). Jelen tanulmány röviden áttekinti az alkoholmentesített, illetve csökkentett alkoholtartalmú borok iránti kereslet egyes jellemzőit, a fogyasztói megítéléseket, foglalkozik az alkoholnak az egészségre gyakorolt hatásaival, továbbá egy megalapozó kutatás eredményeire támaszkodva kitér az alkoholmentesített, illetve a csökkentett alkoholtartalmú borokat elfogadók alkoholfogyasztással kapcsolatos attitüdjeikre.

\section{SZAKIRODALMI ÁTTEKINTÉS -} LITERATURE REVIEW

\subsection{Az alkohol egészségre gyakorolt hatásai - The Effects of Alcohol on Health}

A bor mintegy 200 szerves és szervetlen vegyületet tartalmaz. Kémiai összetétele három csoportba osztható. A szőlőből származó vegyüle- tekre, az erjedés során képződött molekulákra és a kívülről bekerült anyagokra. Utóbbiban, vagyis a kívülről bekerült vegyületek közül a növényvédőszer-maradványok jelentik a legnagyobb veszélyt a fogyasztókra. Ezek azonban nemcsak a borok esetében jelentenek komoly egészségügyi kockázatot és nem kapcsolódnak a bor alkoholtartalmához. Ezeknek a vegyületeknek egy része már a szőlőben is megtalálható, más részük az alkoholos erjedés, valamint az ászkolás, illetve a bor hordóban történő tárolása során alakul ki. A szőlőbogyók esetében a cukortartalom a lényeges, a cukrok meghatározó jelentőségűek a mustban, mivel a borokban megtalálható alkohol képződéséhez szükségesek (KÁDÁR, 1982).

Az alkohol grammja kétszer annyi energiát tartalmaz, mint ugyanannyi fehérje vagy szénhidrát (DRINKWARE, 2021). Az American Journal of Clinical Nutritionban megjelent tanulmány eredményei között szerepel, hogy az elhízásban nemcsak az alkoholos italok, hanem a mellette elfogyasztott több zsíros és egészségtelen étel is szerepet játszik (BRESLOW et al., 2013). A borban megtalálható biológiailag aktív polifenolok növelik az erek belső borítását adó sejtek nitrogén-monoxid-képző tulajdonságát. A nitrogén-monoxid értágító anyag, így csökkenti a vérnyomást (MATOS, 2012). A barcelonai egyetem kutatói a gin, a vörösbor és az alkoholmentes vörösbor vérnyomáscsökkentő és nitrogén-monoxid-termelő hatását vizsgálták. A kutatás azt eredményezte, hogy az alkoholmentes vörösbor fogyasztásának hatására a vérnyomás jelentősen csökkent, míg a nitrogén-monoxid-szint pedig kifejezetten növekedett. Ez a tény 20\%-kal csökkentené az agyi katasztrófák előfordulását (CHIVA-BLAN$\mathrm{CH}$ et al., 2012). Megállapítható, hogy az egészségügyi elváltozások és az alkoholfogyasztás között számos esetben összefüggés van. Az alkoholtartalmú italok fogyasztása a központi idegrendszerre károsan hat, mert csökkenti az agykérgi gátlásokat, izgatottságot, eufóriát okoz, a képzettársulások torzulnak, a nyálelválasztás és a gyomornedv elválasztása fokozódik. A nemi vágy is fokozódik-, a teljesítőképesség viszont csökken. Kevés alkohol mértékletes fogyasztása inkább csökkenti, a nagy mennyiségben fogyasztott alkohol viszont növeli a heveny infarktus veszélyét, kiváltképp idős korban. Az 
alkohol és az infarktus összefüggése országról országra különböző. Kanadai kezdeményezésre világméretű vizsgálat kezdődött a szívinfarktus kockázati tényezőinek tanulmányozására INTERHEART elnevezéssel. „A heveny infarktusnak kilenc, könnyen ellenőrizhető kockázati tényezőjét azonosították: a dohányzást, a hipertóniát, a táplálkozási tényezőket, a vérzsírok szintjét, a mozgáshiányt, a diabéteszt, a kövérséget, az alkoholfogyasztást és a pszichoszociális körülményeket” (OTSZONLINE, 2014). A kutatás során megállapították, hogy míg a nagymértékű alkoholfogyasztás ( $\geq 6$ egy- ség ital az infarktust megelőző 6 órában) növelte, addig a mérsékelt fogyasztás csökkenti az infarktus kockázatát. Az úgynevezett standard unit, vagyis egységnyi alkohol, amit az emberek szervezete képes óránként lebontani, 8-12 gramm alkoholt jelent. Ez 1 deciliter bor alkoholtartalmának felel meg. Ez az egység 10 ml vagy 8 gramm alkoholnak felel meg a brit ajánlás szerint (LÉGRÁDY, 2019). Az egyes borospohár méretekhez és a százalékos alkoholtartalomhoz illesztett egység beosztás az 1. ábrán látható.

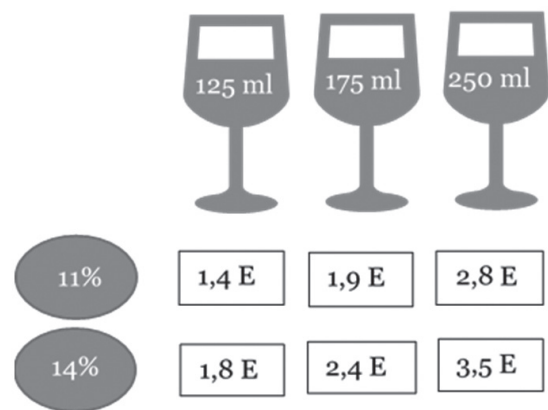

1. ÁBRA

Az egyes borospohár méretekhez és százalékos alkoholtartalomhoz illesztett egység beosztás (Unit Scale for Each Wine Glass Size and Alcohol Percentage)

Forrás (Source): LÉGRÁDY, 2019

A Lancet által közzétett tanulmány megcáfolja azt a tévhitet, hogy a mérsékelt alkoholfogyasztás jótékony egészségügyi hatásokat válthat ki. A vizsgálatok alapján arra jutottak, hogy az alkoholfogyasztás egyaránt növeli a stroke kockázatát és vérnyomás emelkedését, mely következtetés szemben áll a széles körben elterjedt közfelfogással. Gakidou a Washingtoni Egyetem professzora és a Lancet-ben olvasható tanulmány egyik szerzője szerint a kutatás eredményének tükrében arra a következtetésre jutottak, hogy „...az alkoholfogyasztás, menynyiségétől függetlenül, egészségkárosodáshoz vezet a lakosság körében" (GAKIDOU, 2018:1025).

A Lancetben 2018-ban a szerzők által közzétett 195 országra kiterjedő globális tanulmány 243 intézmény, 512 kutató eredményeit gyüjtötte össze az 1990 és 2016 közötti időszakban.

A tanulmány kimutatta, hogy 2016-ban világszerte hárommillió haláleset tulajdonítható az alkoholfogyasztásnak. A Lancet tanulmány alátámasztja a WHO által javasolt költséghatékony beavatkozások fejlesztését és szükségességét, mint az alkohol elérhetőségének korlátozása, marketingjének csökkentése és az alkohol árának növelése (WHO, 2014). Az alkohol nagymértékű fogyasztása ellen szól az is, hogy ilyen esetben már akut mérgezés, inkoordinált mozgás, beszédzavar, ingerlékenység, öntudatlanság, kóma és akár légzésleállás is beállhat. A krónikus károsodások közül fontos kiemelni a gyomorhurutot, az étvágytalanság megjelenését, súlyosabb esetben májcirózis-sárgaság, hasnyálmirigygyulladás és az immunrendszer károsodása mellett súlyos gyulladások (pl. tüdőgyulladás) és az emlőrák kialakulásának fokozott veszélyét (MAGYAR és PETRÁNYI, 1974). A nagy mennyiségben történt alkoholbevitel hatására megnövekedik a véralkoholszint. Túlzott alkoholfogyasztás esetén a növekvő véralkoholszintnek megfelelően különböző élettani tünetek figyelhetőek meg. 
A vérben mért véralkoholszint beosztás szerint ittasság esetén (0,5-1,5 ezrelék) szapora a pulzus, emelkedik a vérnyomás, szapora a légzés, oldottabbak a gátlások, az arc kipirul, bő a verejtékezés és a vizeletkiválasztás, részegség esetén (1,5-2,0 ezrelék) alacsony a vérnyomás, szédelgés, hányás, egyensúlyzavar, lassultság, néha agresszió jelentkezik, alkohol mérgezésnél (2,5 ezrelék felett) gyenge a pulzus, felületes a légzés, eszméletlenség vagy beszükült tudat mutatkozik, vizelet- és bélsárürítés jelentkezhet, súlyos alkohol mérgezés alkalmával (3,5 ezrelék felett esélyes, 5 ezrelék felett biztos) szúk, fénymerev a pupilla, eszméletlenség, kóma áll be, súlyosabb esetben pedig légzésbénulás jelentkezik (LÉGRÁDY, 2019).

$\mathrm{Az}$ alkohollal és egészséggel foglalkozó európai információs rendszer (EISAH) statisztikája szerint óriási egyenlőtlenségek figyelhetőek meg az alkoholfogyasztás következtében bekövetkezett halált okozó balesetek és következményes betegségek között Kelet- és Nyugat- Európa tekintetében. Megállapítható, hogy az ivás gyakorisága és az elfogyasztott mennyiség kombinációjának egyenlőtlensége a régiók között ugyanúgy megmutatkozik az egészség és a társadalmi károsodás vonatkozásában. A halált okozó májcirózis, a daganatos és kardiovaszkuláris betegedések előfordulásának a rizikója hétszeres a kelet-európai régióban a nyugati- és a mediterrán európai régióhoz képest (WHO, 2014). Az alkoholos italok legfontosabb rákkeltő anyaga maga az etil-alkohol, a hatás egyértelmüen függ a napi/ heti dózistól. Az etil-alkohol az alkohol-dehidrogenáz hatására acetaldehiddé metabolizálódik, ami egyértelműen karcinogén. A krónikus alkoholfogyasztás befolyásolja az endogén hormonok termelődését, hatással van az inzulinszerü növekedési faktor 1-re, megváltoztat számos biológiai jelátviteli utat, egyebek mellett oxidatív stresszt vált ki és génkárosodást is okozhat. A napi kis mennyiségü alkohol is növeli az emlőrák kockázatát (NAGYKÁLNAI és LANDHERR, 2018). Az alkohol számos negatív hatásának vizsgálata mellett számos tanulmány pozitív hatásokat is feltárt. „Az alkoholt nem fogyasztók kardiovaszkuláris rizikója kicsit magasabb, mint a mérsékelt, napi 12-24 gramm alkoholnak megfelelő italt fogyasztóké. Ugyanakkor a nagyivók életkilátásai az alkohol toxikus hatásai nyomán kialakuló megbetegedések (pl. cirózis, májrák,stb.) miatt sokkal rosszabbak voltak" (LUGASI, 2000:10). A tanulmányában összefüggést mutat ki a franciák mérsékelt vörösbor fogyasztása és a csökkent kardiovaszkuláris rizikó között, emellett rámutat arra is, hogy a trombózis kialakulását is gátolhatja. Franciaországban megfigyelhető, hogy a magas zsírtartalmú ételek fogyasztása ellenére is alacsonyabb a szívbetegségek morbiditása és mortalitása, mint a vizsgált többi hasonlóan fejlett ország lakosai körében, mely jelenséget „francia paradoxon”-nak neveznek és összefüggésbe hozzák a franciák vörösbor fogyasztásával.

\subsection{A francia paradoxon - The French Paradox}

Az alkohol, közelebbről borfogyasztás és az egészségre gyakorolt hatásukkal kapcsolatos írásokból ritkán maradhat ki a francia paradoxon fogalma és az arra való hivatkozás. A francia paradoxon lényege, hogy a sok zsiradékot tartalmazó francia étrend - fóként magas sajt-, vaj- és állatizsiradék-fogyasztás - ellenére a szív- és érrendszeri megbetegedések száma Franciaországban alacsonyabb, mint más, átlagosan kevesebb zsírt fogyasztó országokban (RÁBAI et al., 2017).

A francia paradoxon fogalmának a borfogyasztásra gyakorolt legnagyobb hatását az Egyesült Államokban figyelhettük meg. Úgy a franciák, mint az észak-amerikaiak élelmiszerfogyasztásában igen magas a telített zsírok bevitele, mindkét populációra jellemző a dohányzás, valamint a mozgásszegény életmód. Mindhárom tényező ezeknek a betegségeknek jelentős rizikófaktora. Ugyanakkor a szív- és érrendszeri megbetegedések aránya Franciaországban lényegesen alacsonyabb volt, mint az Egyesült Államokban. Ezt 1992-ben francia kutatók Renauld és De Lorgeril orvos-földrajzi vizsgálataik során erősítették meg, hogy Franciaországban a szívkoszorúér betegségekből eredő halálozási ráta, összehasonlítva más nyugat-európai országokéhoz képest sokkal alacsonyabb hasonló összetételü és menynyiségű zsírfogyasztás és dohányzás mellett is (TAKÁCS, 2010). Hasonló megállapítás olvasható egy 2017-ben megjelent tanulmányban is, 
melyben kitérnek a szerzők arra, hogy a paradoxon titka a mediterrán étrend mellett a fokozott polifenol tartalom (HASEEB et al., 2017). Az okokat vizsgálva először a mérsékelt etil-alkohol fogyasztásnak tulajdonították, lévén, hogy az alkohol, nevezetesen a borfogyasztás volt az egyetlen faktor, amiben jelentős különbség mutatkozott, de ez önmagában nem bizonyult elégségesnek. A borban előforduló polifenolok és polifenol- típusú vegyületek ebből a szempontból kedvezően hatnak.

Kutatások bebizonyították, hogy a nagytestû, mély színü vörösborok az antioxidáns anyagok leggazdagabb forrásai, a bennük található rezveratrol csökkentheti a szív- és érrendszeri betegségek valószínűségét. Az Egyesült Államokban a francia paradoxon jelenségét 1991ben egy rádióműsorban ismertették, hatására rövid időn belül megnégyszereződött az USAban a borfogyasztás, és az ismertetésben szereplő szőlőfajta, a merlot pár év leforgása alatt a világ egyik legnépszerúbb, legnagyobb területen telepített szőlőfajtája lett.

\subsection{Az alkoholtartalom csökkentése, az alkoholmentesítés - Reduction of Alcohol Content, Alcohol Removal}

A csökkentett és alkoholmentes borok előállítása többféle módon is történhet, egyrészt fordított ozmózissal, másrészt vákuumdesztilláció során. Mindkét eljárás esetében a már meglévő, magasabb alkoholtartalmú borból készül a megváltoztatott alkoholtartalmú ital. A két eljárás mellett létezik egy olyan formája is az előállításnak, amely esetben nem csökkentik az alkoholtartalmat, hanem eleve alkoholmentes bort állítanak elő. Ennek az eljárásnak az a lényege, hogy az erjedési folyamatot abban a pillanatban állítják le, amikor a szőlőben található cukor alkohollá kezd alakulni. A borok alkoholtartalmának a csökkentésével az antioxidánsok nem tűnnek el a borból. Francia kutatók kimutatták, hogy a cabernet sauvignon esetében, ha az eredeti 12\%-ról 6\%-ra csökkentik a bor alkoholtartalmát a kardiovaskuláris rendszernek fontos antioxidánsok nem tünnek el a borból. Ebból arra következtettek, hogy a szívbetegek panaszainak kezelésére a csökkentett alkoholtartalmú és alkoholmentesített vörösborok kifejezetten jó hatásúak (LAMONT et al., 2012).
A csökkentett alkoholtartalmú vagy alkoholmentesített bor fogyasztása is megoldást jelenthet az alkohol okozta veszélyeztetésekkel szemben. Az alkoholtartalom csökkentésének, a csökkentett alkoholtartalmú borok előállításának több módja is ismert. A must erjeszthetô alkoholtartalmának a csökkentése elérhető a koraérett gyümölcs felhasználásával, szőlőlével való hígítással, kifagyasztással és frakcionálással, glükóz oxidáz enzim hozzáadásával. A másik módszer a borból az alkohol kivonása termikus eljárásokkal (atmoszférikus vagy vákuum desztilláció, bepárlás), kifagyasztással, membránszeparációval (dialízis, fordított ozmózis, ozmotikus desztilláció, pervaporáció, nanoszűrés, membránextrakció), adszorpcióval (gyanta vagy szilikagél alkalmazásával), extrakcióval (direkt extrakció szerves oldószerekkel, szuperkritikus extrakció széndioxiddal). Az egyéb módszerek közé tartozik a bor hígítása, a fermentáció korai leállítása, alacsony alkoholkoncentrációt produkáló élesztőtörzs alkalmazása és a fenti eljárások kombinálása (PICKERING, 2000).

A fenti módszerek egy részét már Takács is leírta 2010-ben, hogyan csökkenthető a must szénhidráttartalma a szüret előbbre hozásával, kifagyasztással és frakcionálással, a must szőlőlével történő hígításával, valamint a musthoz történő glükóz oxidáz enzim hozzáadásával. Lehetséges tehát a borból történő alkoholkivonás, ennek is számos módja ismert.

A csökkentett alkoholtartalmú borok készítése az 1970-es évek elejére nyúlik vissza, azonban a kezdeti érdeklődés nevezetesen, az alkoholtartalom csökkentése minőségi (élvezhetőségi) gondokat eredményezett. Ugyancsak történtek próbálkozások az 1980-as években is, azonban az igazi áttörést a technológia fejlődése mellett a fogyasztói szokásokban bekövetkezett változások és az említett termékekkel kapcsolatos marketingtevékenység erősödése hozta meg.

$\mathrm{Az}$ ismertetett megoldások közül a termikus vákuum desztilláció és a fordított ozmózis a leginkább alkalmazott módszer (TAKÁCS, 2010). Az európai borkészítési szabályozásban 2010-ben kerültek be azok az engedélyezett eljárások, amelyekkel csökkentett alkoholtartalmú borokat lehet előállítani. A szabályozás az eredeti alkoholtartalomnak 2 térfogatszáza- 
lékkal történő csökkenését engedélyezi, de el kell érniük legalább a 8-10 térfogatszázalékot. Amennyiben 2 térfogatszázaléknál nagyobb mértékben csökkentik az alkoholtartalmat, ebben az esetben a megjelölés „részben alkoholmentesített borból készült ital” vagy „szőlőből készült ital" lehet.

Alkoholmentes bor esetén a tényleges alkoholtartalom legfeljebb o,5 térfogatszázalék lehet. Az ilyen terméknél a „boralapú ital” megjelölést alkalmazzák, mert ezek a borok az általános élelmiszertörvény hatálya alá esnek. Miután nem tartoznak a bortörvény hatálya alá, ezért a jövedéki adótörvény nem vonatkozik rájuk, hiszen ezek az italok hivatalosan sem számítanak bornak (NJT, 2021).

Az előállítóknak nagy kihívást jelent, hogy hogyan lehet az alkoholtartalmat úgy csökkenteni, hogy közben az aromák megmaradjanak és a termék magas élvezeti értékủ maradjon. A csökkentett alkoholtartalmú borok vagy alkoholmentesített bor alapú termékek találkoznak az egészségpolitikai célkitűzésekkel, valamint a fogyasztók ízlésének változásával is. Ezeket a borokat kereső fogyasztók kifejezetten odafigyelnek az étkezésükre és az alakjukra (SIDLOVITS, 2019).

$\mathrm{Az}$ alacsonyabb alkoholtartalmú borok azt az imázst keltik, hogy könnyü, alacsony kalóriatartalmú italokról van szó. Ezen italok előnye, hogy azok is fogyaszthatják, akik valamilyen betegséggel, például cukorbetegséggel, alkoholproblémákkal és gyógyszerszedéssel küzdenek. Kellemes érzetet biztosítanak akkor is, amikor nem lehet alkoholt fogyasztani, vallási okokból, autóvezetésnél, hivatásos sofőröknél, terheseknél, meleg időjárás miatt, 18 év alatt, gyermekeknél és nyugdíjas otthonokban.

\subsection{Nemzetközi kitekintés a fogyasztói megítélésre - An International Overview on Consumer Perception}

A kereskedelemben két évtizede elérhetőek a csökkentett alkoholtartalmú borok, ezek megjelenése sokrétű marketing és technológiai változtatást és kihívást igényel.

Pickering már a 2000-es évek elején megállapította, hogy azok az eljárási technológiák, amelyek a csökkentett borok előállításához szükségesek, drágák és nem feltétlenül váltják be a gyártók értékesítési volumenhez füzött reményeit. Annak érdekében, hogy magasabb piaci részesedést érjenek el ezek a termékek, fokozni szükséges a termékek ismertségét, a hitelességet és növelni az elfogadottságot reklám- és promóciós tevékenységgel (PICKERING, 2000).

Ausztráliában, 2013-ban végzett kutatás megállapította, hogy az alacsony alkoholtartalmú borok elfogadottsága fokozatosan nő, a vizsgált évben már 16\%-os volt. Ez a százalékos arány 40\%-ra ugrik, ha az íz a megszokott, alkoholtartalmú bor ízével megegyezik (SALIBA et al., 2013). A csökkentett alkoholtartalmú borok esetében meghatározó lehet a címkén használt nyelvezet, mert a használt szavak eltérő módon hatnak a fogyasztói viselkedésre, ezáltal csökkenthetik a termék vonzerejét és eladhatóságát (VASILJEVIC et al., 2018 a). A szerzők egy másik tanulmányukban arra is rámutattak, hogy, ahogy a címkén feltüntetett alkohol százalékos tartalma csökken, úgy növekszik az elfogyasztott mennyiség (VASILJEVIC et al., 2018 ).

BOSHUIZEN (2020) vizsgálati eredményei szerint a csomagolásnál nem jelent előnyt az atípusos palackforma és atípusos címke az alkoholmentes borok forgalmazásánál és megállapította, hogy az alkoholtartalmú borok címkéjéhez hasonló, tipikusan egységes csomagolás hozta a legjobb eredményt a fogyasztói megítélésben.

A globális felmelegedés következtében a szőlőben egyre magasabb a cukortartalom, ez pedig a borokban egyre magasabb alkoholtartalmat eredményez. Ugyanakkor a borfogyasztók egy része egyre inkább az alacsonyabb alkoholtartalmú borokat keresi. SIDLOVITS (2019) kitér arra, hogy az erre irányuló technológiai és fogyasztói kutatások fóként Dél-Franciaországban kezdődtek, melyek a borok fogyasztói megítélésére és az alkoholtartalom csökkentésére irányultak. Nagy-Britanniában és Franciaországban csökkentett alkoholtartalmú borok fogyasztói megítélését vizsgálták 1000 borkóstoló bevonásával 3 éven keresztül. A kóstolók között voltak új fogyasztók és tapasztalt borfogyasztók is. A kutatásba bevont fogyasztók közül az új borfogyasztók a vakteszt során sokkal jobbnak értékelték a csökkentett alkoholtartalmú borok ízvilágát, míg a tapasztaltak csalódottak voltak. Ugyanilyen különbség volt 
abban az esetben is, ha rendelkezésre állt az az információ, hogy milyen bormintát kóstolnak. A vizsgálat azt mutatta, hogy a termékek megítéléséhez egyértelmüen hozzájárulnak a pszichológiai tényezők (imázs, prekoncepció) és az érzékelt jellemzők, például az íz. A vörös és fehérborok esetében ugyancsak különbség volt a fogyasztók típusától függően, a fehérborok jóval elfogadottabbak voltak a vörös boroknál. 2018-ban 12 ezer fogyasztó körében végeztek felmérést, amely kiterjedt a világ 11 bortermelő országára, a felmérést a Wine Intelligence végezte a csökkentett alkoholtartalmú borok fogyasztói megítélésére. Speciális indexeket dolgoztak ki az alternatív bortípusokra. Ezen bortípusok termékkörének elnevezése SOLA wines. A mozaikszó az alábbi bortípusokból tevődik össze: sustainable wine (fenntartható gazdálkodásból származó borok), organic wine (bioborok) és lower-alcohol wine (csökkentett alkoholtartalmú borok). A SOLA Opportunity Index az a mutató, amely a tudatosságot (a fogyasztó tudja, ismeri, tudja mit jelent), a vásárlási szándékot (hajlandó megvásárolni) és az affinitást (a termék pozitív hatásait értékeli) foglalja magában, és megmutatja, hogy az alternatív bortípusok az egyes országokban milyen piaci potenciállal rendelkeznek. A legjobb eredményt a bioborok érték el, rosszabb helyezést kaptak az alacsony alkoholtartalmú borok, utolsó helyen pedig az alkoholmentes boralapú italok szerepelnek (SIDLOVITS, 2019).

Az alábbi felsorolás mutatja, hogy a csökkentett alkoholtartalmú és alkoholmentesített borok a piacon mely országokban az inkább elfogadottak, illetve a kevésbé elfogadottak. A csökkentett alkoholtartalmú borok esetén a leginkább elfogadó országok Új-Zéland és Ausztrália, a legkevésbé pedig Németország, Svédország és Japán voltak. Az alkoholmentesített borok esetén a leginkább elfogadó országok Németország és a skandináv országok, elsősorban Svédország. Legkevésbé pedig Japánban és Portugáliában kedvelik ezeket a termékeket. A kereskedők potenciális piacot látnak a muzulmán országoknál, a Közel-Keleten, de hasonló jelentős kereslet mutatkozik Németországban és Hollandiában is. Az alkoholmentes termékek vagy alacsonyabb alkoholtartalmú borok esetén akkor van a fogyasztónak nagyobb bizalma, ha ismert borászat vagy elis- mert védjegy alapján a termék beazonosítható (HALSTEAD és ABERNATHY, 2018).

Franciaországban is egyre több borászat forgalmaz csökkentett alkoholtartalmú borokat. Az efféle borok külön szabályozás alá esnek és ezekre a termékekre külön elnevezést használnak, mégpedig a „csökkentett alkoholtartalmú minőségi bor" kifejezést, rövidítése VDQA (vins de qulité á teneur réduite en alcohol).

Ezek a borok azonban csak földrajzi jelzéses borként forgalmazhatók, vagyis a 607/2009/ EK rendelet szerint, mely az Európai Unió borreformja alapján létrehozott minősítési kategória. Oltalom alatt álló földrajzi jelzéssel, (OFJ) azok a borok rendelkezhetnek, melyek különleges hírneve vagy egyéb jellemzői az adott földrajzi eredethez kapcsolhatók, jelentős mértékben, minimum $85 \%$-ban az adott földrajzi területen termesztett szőlőból készült, legalább 8 térfogatszázalék alkoholtartalommal rendelkezik és savtartalma eléri a literenkénti 3,5 grammot (HNT, 2021). Ugyanakkor az OFJnél a magasabb kategóriát jelentő oltalom alatt álló eredetmegjelöléssel (OEM) ellátott borok esetében az alkoholtartalom csökkentése Franciaországban nem engedélyezett (SIDLOVITS, 2019).

Nagy-Britanniában a VDQA-borokat bulizó italként pozícionálják, elsősorban a fiataloknak kínálják hétvégi bulikon, másodlagos célcsoport a városi, rendszeresen borfogyasztó 30-50 év közötti nők. A fogyasztók a minőség szempontjából az erős borvédjegyet tekintik a minőség biztosítékának. Az anonim borok esetén egyértelműen negatív a megítélés, sokszor hamisított bornak ítélik. A csökkentett alkoholtartalmú borok megfelelő bevezetése és kommunikációja egyértelmüen hat a fogyasztók körében a megítélésükre. A csökkentett alkoholtartalmú és alkoholmentes boralapú italok a piaci résben jelentkeznek és küzdenek a konkurens termékekkel, ugyanakkor a növekvó fogyasztói kereslet a piaci potenciáljukat növeli. Ezekből a termékekből széles paletta érhetó már el, mind a fehér, mind a vörös és a rosé borokból, szénsavas termékekból (SIDLOVITS, 2019). Beckett a The Guardian étteremkritikusa és borszakírója értékelte a 0,5 térfogatszázalékos borok jelenlétét az angol piacon. Megállapítása szerint az utóbbi években megváltozott a fogyasztók összetétele, az egészségtudatosan 
táplálkozók szegmensének a bővülése egy jóval szélesebb réteg megcélzását teszi lehetővé. Ugyanakkor az alkohol mennyiségének csökkentése, illetve teljes kivonása ezen italok esetében megváltoztatják a termékek ízvilágát, az „ital lelke” is távozik az alkohollal. A minőségi alapanyag és a legmodernebb technológiák alkalmazásának ellenére a o,5 térfogatszázalékos borfajta ízvilága eltér a megszokottól (BECKETT, 2017). A 2016-os brit ajánlás szerint 1 egység megfelel $10 \mathrm{ml}$ vagy 8 gramm etanolnak és nemtől függetlenül 1 hét alatt 14 egység alkoholnál többet nem szabad fogyasztani (LÉGRÁDY, 2019).

A nagy-britanniai Nemzeti Statisztikai Hivatal 2018-ban tanulmányt jelentetett meg az elmúlt tíz év alkoholfogyasztási magatartásá- ról. A vizsgálat különböző korcsoportokra terjedt ki, külön vizsgálták a 16-24, 25-44, 45-64 és 65 év felettiek körében az alkoholfogyasztási magatartást. A 2. ábrán a különböző korcsoportok alkoholfogyasztása látható. Az ábra megmutatja az adott év azon egy napját, amikor a legnagyobb, 6-8 egységet fogyasztották el 2007-2017 között. Jól látható, hogy az adott napon elfogyasztott legnagyobb alkohol bevitel mértéke az elmúlt tíz évben a 16-24 és a 2544 éves korcsoportokban csökkenő tendenciát mutat. A 45-64 éves és a 65 és a fölötti korcsoportokban azonban nem történt lényeges változás. A 2017. évre az állapítható meg, hogy a 65 és a fölötti korcsoporton kívül a többi korcsoportban ez a fogyasztási arány közel azonos lett a vizsgált napon.

\section{2. ÁBRA}

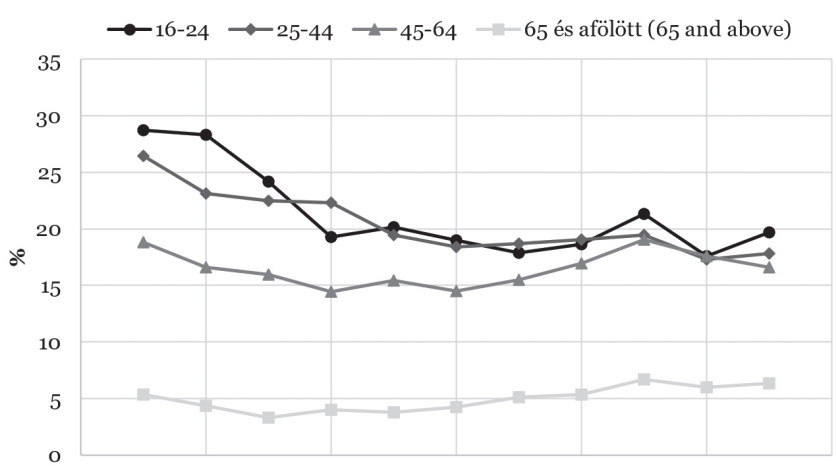

Alkoholfogyasztás a különböző korcsoportokban a legtöbbet fogyasztó napon (2007-2017)

(Alcohol Consumption in Different Age Groups on the Most Consuming Day (2007-2017))

Forrás (Source): DIGITAL.NHS (2018) alapján saját szerkesztés (Authors'own compilation based on DIGITAL.NHS (2018))

A 3. ábra a nem és életkor szerinti vizsgálat eredményeit mutatja. A felmérésben az előző hét azon napja látható, amikor a legtöbbet, több mint 6-8 egységet fogyasztottak a vizsgált csoportok. A férfiak esetében a legalább 6-8 egységet fogyasztók aránya közel azonos volt a korcsoportokban, kivéve a 65 és annál idősebbeket, ahol ez szignifikánsan alacsonyabbnak bizonyult. A nőknél életkorral arányosan, fokozatosan csökkent ezen alkoholfogyasztás aránya.

A fogyasztók felé történő alkoholmentesített borok kommunikációjában az adatok alapján a 16-24 éves korosztályra lenne célszerü fókuszálni, mert az abusus-szerü, nagymértékü alkohol bevitel ebben a korcsoportban figyelhető meg a leginkább. A fenti korosztály alkoholfogyasztási szokásaiba a csökkentett alkoholtartalmú, illetve alkoholmentes borok bevonása lenne ideális. Emellett javasolható az alkoholmentes italok arányának növelése az aktív fogyasztási napjaikon. A korosabb, 65 és annál idősebb korosztály esetében megfigyelhető a fogyasztás csökkenése. Ez a csökkenés nagyrészt az egészségügyi problémák megjelenésével áll összefüggésben. Ebben a korcsoportban is a megfelelő piaci stratégiákkal kellene felhívni a figyelmet a csökkentett és alkoholmentes borok fogyasztására (pl. nyugdíjas otthonokban történő reklámozás, ismeretterjesztés) (DIGITAL.NHS, 2018).

A Global Markets Insights 2019. évi előrejelzése szerint az alkoholmentes borágazat várhatóan 2025-re 8\% feletti növekedést produ- 
kál majd globálisan. A folyamatos növekedés következtében az alkoholmentes sör-és borok piacának forgalma 2025-ig világszinten eléri a 30 milliárd amerikai dollárt. A globális piac növekedését a fogyasztók egészségtudatos magatartása, az életszínvonal javulása és az egészségügyi előnyök magyarázzák. A tudatosság kialakulásában szerepet játszik a digitalizáció térnyerése és a közösségi média véleményformáló hatása is. Az iszlám országokban, például Egyiptomban, Líbiában vagy Iránban az alkoholfogyasztásra szigorú szabályok vonatkoznak, amelyek pozitívan befolyásolhatják az alkoholmentes borok fogyasztásának növekedését. A fogyasztás növekedéséhez az is hozzájárul, hogy a jövedelmek növekednek, illetve a hagyományos, ismert védjeggyel rendelkező prémium termékeket előállító borgyártók is bővítették érékesítési hálózatukat a piacon (KUNAL és RAWAT, 2019).

A Wine Intelligence szerint a technológiai fejlődés, különösen a mobiltelefonok térnyerése miatt az online csatornákon keresztül történő értékesítés egyre elterjedtebb. Ennek is köszönhető, hogy Kínában 2014-ben az alkoholmentes borértékesítés több, mit 50\%-át online áruházakon keresztül bonyolították.

A németországi Heilbronni Főiskola által végzett kutatás eredményei kimutatták, hogy a megkérdezettek szerint a legfontosabb indok az alkoholmentes borok fogyasztására az autóvezetés, a második helyen az egészségügyi okok szerepeltek. A kutatás érdekes eredményt hozott arra vonatkozóan, hogy azok, akik nem fogyasztanak alkoholt, az alkoholmentes borok társaságában nem érzik magukat a rendezvényeken kirekesztettnek. A vizsgálat nem támasztotta azt alá, hogy a „ízkép lelke” elveszik az alkoholmentesítés során, miután a megkérdezettek 51\%-a jónak vagy nagyon jónak értékelte az alkoholmentes bor ízét, csak 16\%-uk találta rossznak vagy nagyon rossznak (FREYTAG, 2019). BUCHER és szerzőtársai (2018) leíró tanulmányukban az alacsony alkoholtartalmú borfogyasztással foglalkozó kutatások irodalmát tekintik át, fókuszálva az alacsony alkoholtartalmú borok fogyasztásához kapcsolódó szokásokra, viselkedési formákra. A legtöbb kutatást az alacsony alkoholtartalmú borokról Ausztráliában végezték. Azonban országonként eltérő lehet a fogyasztás és a hozzáállás, ezeknek a különbségeknek a feltáró vizsgálatára a késóbbiekben szükség lehet. SALIBA és MORAN (2010) felmérésében 1050 felnőtt borfogyasztót kérdezett meg arról, hogy az alacsonyabb alkoholtartalmú borból gyakrabban és nagyobb mennyiséget fogyasztanak-e. Az eredmény azt mutatta, hogy nagyobb gyakorisággal, de mennyiségi növekedés nélkül fogyasztják ezeket a borokat, így a teljes alkoholfogyasztás mértéke jelentősen csökkent. BUCHER és szerzőtársai (2018) is hasonló eredményre jutott tanulmányában, az alacsony alkoholtartalmú bort fogyasztók a hagyományos borivókkal szemben körülbelül 30\%-kal kevesebb alkoholt ittak.

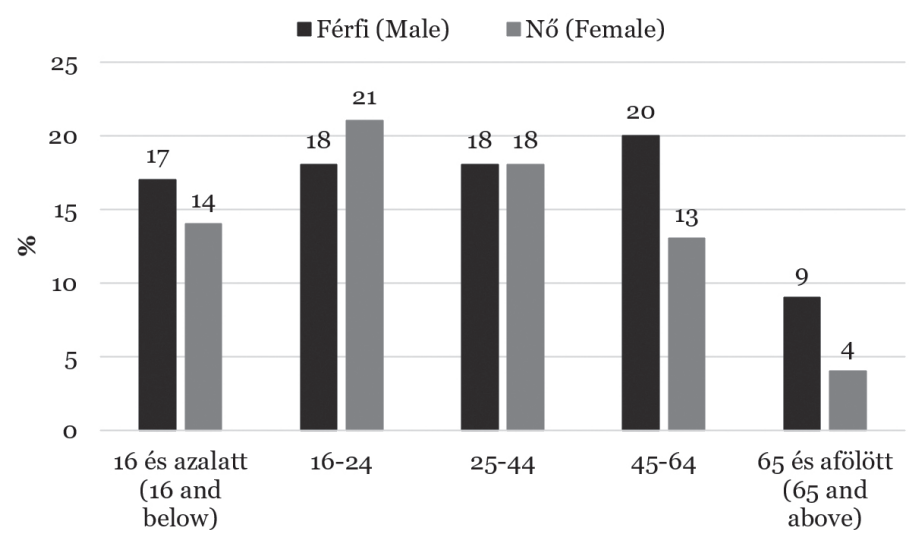

3. ÁBRA

Alkoholfogyasztás a legtöbbet fogyasztó napon nem és életkor szerinti megoszlás (Alcohol Consumption on the Day of Drinking the Most Distribution Based on Gender and Age)

Forrás (Source): DIGITAL.NHS (2018) alapján saját szerkesztés (Authors'own compilation based on DIGITAL.NHS (2018)) 


\subsection{Kampányok az alkoholfogyasztás csökkentésére, „száraz hónapok” - Campaigns to Reduce Alcohol Consumption, "Dry Months"}

Az egészséges életmód előtérbe kerülésével különböző száraz hónapok kerültek meghirdetésre hazánkban és a világ különböző országaiban.

Az Y generáció (1980-1995 között születettek) körében komoly változások észlelhetőek az alkoholfogyasztást illetően, a fiatalok magatartása érdekes átrendeződést eredményezhet a piacon. Ebben az átrendeződésben a közösségi média is szerepet játszik, hisz manapság már kimondottan kellemetlen lehet egy rossz, alkoholos befolyásoltság alatt készült kép feltöltése a közösségi hálóra, mely maradandóbb és súlyosabb következményekkel is járhat, mint mikor ezek a platformok még nem léteztek.

„A korábbi generációk kevésbé voltak tájékozottak az élelmiszerek egészségügyi hatásaival kapcsolatban, a fiatalok erre nagyon odafigyelnek. Sokkal jobban informáltak az olyan témákban, hogy az alkohol hogyan befolyásolja a járművezetési képességeiket, mik az egészségügyi hatásai és mennyire hízlal" (SCHULTZ, 2019). Hazánkban 2010-ben a Magyar Szeszipari Szövetség és Terméktanács útjára indította HAFRAC (Magyar Szövetség a Felelős Alkoholfogyasztásért) elnevezésű programját. Ez a program felvilágosító és ismeretterjesztő anyagokból áll abból a célból, hogy a magyarországi alkoholfogyasztási szokásokat jobb irányba terelje. A 2-3-4-o program a mérsékelt alkoholfogyasztásra hívja fel a figyelmet. A program kialakításánál figyelembe veszik a kort, a nemet, az életvitelt és az egészségügyi állapotot is.

A Száraz November kampányt ugyancsak hazánkban a Kék Pont Alapítvány 2019-ben szervezte meg immár negyedik alkalommal. Az alapítvány programja a mérsékelt alkoholfogyasztást népszerüsíti, ugyanakkor kerülni kívánja a kontrollálatlan fogyasztás kialakulását (MEDICALONLINE, 2019).

Nagy-Britanniában 2013-ban az Alcohol Change UK nevü szervezet hozott létre egy hasonló programot „Dry January” néven az ivás káros hatásainak megakadályozására. 2021 januárjában már 6,5 millió brit állampolgár vett részt benne (ALCOHOLCHANGE, 2021).

\subsection{A borfogyasztás alakulása Magyar- országon - Tendencies of Wine Consumption in Hungary}

Magyarország a hagyományos borfogyasztó országok közé tartozik, az egy főre jutó éves fogyasztás mintegy 25l/fő (STADAT-4.1.2.1.11. BORMÉRLEG 1970-).

Az éves fogyasztás mennyisége az elmúlt időszakban is e körül alakult, azonban az egyes évek között bizonyos, több tényezőre is viszszavezethető ingadozás figyelhető meg. Ezek a tényezők leginkább az import, illetve a helyettesítő termékek marketingaktivitása által befolyásoltak. A borfogyasztás, és a fogyasztói magatartás kutatása a népszerü kutatási témák közé tartozik, ezért viszonylag rendszeres időközönként találkozhatunk jelentős minta elemszámot magában foglaló kutatásokkal (TOTTH és SZOLNOKI, 2019).

A legutóbbi, nem, kor, településnagyság és régiók szerint reprezentatív felmérést a HNT megbízásából 2017-ben készítették (SZOLNOKI és TOTTH, 2018). A felmérésből megállapítható, hogy Magyarországon a 18 év feletti lakosság közel kétharmada tekinthető borfogyasztónak, és ezek fele minimum havi gyakorisággal teszi azt. A legalább heti gyakorisággal bort ivók fogyasztják a teljes mennyiség kétharmadát. Szignifikánsan nagyobb fogyasztás jellemzi a férfiakat, a középkorosztályba tartozókat. A vagyoni státusz csökkenésével csökken a borfogyasztás, mely regionálisan is különbségeket hordoz magában, a Dunától (amely sok egyéb fogyasztói szempontból is választó vonal) nyugatra nagyobb mennyiségben fogyasztanak, mint attól keletre (TOTTH és SZOLNOKI, 2019). Az említett tanulmány foglalkozott a borfogyasztás elutasításának okaival is.

Jelen kutatásunk szempontjából érdekes, hogy a felnőtt lakosság harmada nem fogyaszt bort, melyet alapvetően három okra vezethetünk vissza. A borok ízére, akik nem szeretik a bor ízét, azok zömmel sört fogyasztanak, egészségügyi okokra, illetve az alkoholfogyasztás teljes elutasítására. Látható, hogy ennek a kb. 2.750 ezer főnek egy része potenciális piacot jelenthet az alkoholmentesített, illetve csökkentett alkoholtartalmú borok számára. TURCSÁN és szerzőtársai (2018) az alkoholos és az alkoholmentes italokkal kapcsolatos fogyasztá- 
si szokásokat mérte fel, kiemelt figyelemmel az alkoholmentes borra. Felmérésüket 2018-ban 18 éven felüliek körében, nem reprezentatív, online kérdőíves módszerrel végezték, a kérdőív 24 kérdést tartalmazott, melyet 210-en töltöttek ki. A kérdőívben demográfiai adatok mellett végzettséggel, jövedelemmel, alkoholfogyasztási attitúdökkel, alkoholmentesített italok fogyasztásával, az alkohol és alkoholmentes italok egészségre gyakorolt hatásaival kapcsolatos kérdések szerepeltek. Egy kérdés az alkoholmentesített preferált bormárkára vonatkozott. A tanulmány alapján megállapítható, hogy a nők inkább választanak alkoholmentesített italokat, mint a férfiak. Az alkoholmentesített bort senki nem jelölte fogyasztott italként, inkább az alkoholmentes sört és pezsgőt részesítették némileg előnyben. Az alkoholmentes pezsgő („kölyökpezsgő”) nem tartozik az általunk vizsgált kategóriába, ugyanis semmi köze nincs az alkoholokhoz, nem csökkentett, vagy alkoholmentesített termékről van szó! Az eredmények azt mutatták, hogy nincs számottevő kereslet az alkoholmentes, illetve az alkoholmentesített borok iránt.

\subsection{A borfogyasztás elutasítása és a borral kapcsolatos attitúdök - Refusal of Wine Consumption and Attitudes Towards Wine}

A csökkentett alkoholtartalmú, illetve az alkoholmentesített borok várható fogyasztói elfogadását tekintve érdekes lehet azoknak az okoknak az ismertetése, amelyek a borfogyasztás elutasítását eredményezik.

Ebből a szempontból az elmúlt évtizedek számottevő borfogyasztói magatartás kutatásai OSZKỐ (2003), GFK (2008), TURIZMUS BULLETIN (2013), HNT: SZOLNOKI és TOTTH (2017), gyakorlatilag hasonló arányt és azonos indokokat mutattak, illetve tártak fel. Egyedüli kivétel a vizsgáltunkba vont első kutatás, mely a vizsgált reprezentatív minta alapján a többi kutatásnál lényegesen magasabbra, 38\%-ra tette a bort egyáltalán nem fogyasztók arányát és 20\%-ra azokét, akik ritkán, tehát a havi gyakoriságnál ritkábban fogyasztanak bort (OSZKŐ, 2003).

A többi idézett tanulmány szerint a 18 év felettiek mintegy harmada tartozik a borfo- gyasztást elutasítók közé. Az okok, mint már említettük, gyakorlatilag három csoportba voltak sorolhatók (SZOLNOKI és TOTTH, 2018). Az ugyancsak hivatkozott GFK felmérés szerint az elutasítás mintegy fele-fele arányban az általános alkohol elutasításra, (ezen belül 37\% antialkoholista, 21\% egészségügyi okok miatt), illetve konkrétan a bort elutasítására, (ezen belül 43\% nem szereti 37\% mást szeret inkább) volt visszavezethető (GFK, 2008).

\section{ANYAg ÉS MódSZER - MATERIAL} AND METHOD

Vizsgálataink során az alkoholmentesített, illetve alkoholcsökkentett borok fogyasztásának szakirodalmi feldolgozása mellett, feltáró kutatást végeztünk az $\mathrm{Y}$ és a $\mathrm{Z}$ generációk körében ezen termékkör ismertségével, és a hozzájuk füződő attitűdökkel kapcsolatosan. A feltáró kutatást leggyakrabban valamilyen piaci probléma megismerésére, egy bizonyos helyzet megismerésére alkalmazzuk, melynek esetünkben alapvetően két célja volt, egyrészről további kutatások számára prioritások megállapítása, valamint hipotézisek felállítása, ugyancsak a további kutatások számára (MALHOTRA, 2001). Önkényes mintavételt alkalmaztunk, a minta a két említett generációra terjedt ki és nem volt reprezentatív. A kérdezés online történt. A szakirodalom az internetes megkérdezés számos előnyét tarja nyilván. Ezek közé sorolja az adatok megszerzésének a gyorsaságát, az ellenőrzés lehetőségét, illetve a kérdezői torzítás kizárását, valamint a viszonylag alacsony költségeket. A megkérdezéssel párhuzamosan bolti megfigyelést alkalmaztunk, mely kiterjedt a borok forgalmazására szakosodott online üzletekre, weboldalakra is. A megfigyeléses vizsgálat az FMCG termékeket forgalmazó valamennyi csatornatípusra- hiper-, szupermarket, $\mathrm{C} \& \mathrm{C}$, diszkont, kisbolt- kiterjedt, és az adott üzlettípusban kapható csökkentett alkoholtartalmú, illetve alkoholmentesített borok kínálatának feltérképezését szolgálta. Magyarországon összesen 14 üzlet, 4 hazai webáruház alkoholmentesített, illetve csökkentett alkoholtartalmú bor kínálatán túl számos vendéglátóhely és bár online itallapját is elemeztük. Hasonlóképpen áttekintettük több ausztriai üzlet - Billa, 
Lidl, Interspar, Merkur - honlapját, valamint megnéztük több osztrák webáruház honlapját. A felmérésre 2020. október hónapban került sor. A beérkezett válaszok száma 643 , ebből értékelhető válaszok száma 640 volt. Az adatok feldolgozása az SPSS 27.0.1.0-val történt. A minta összetételét az 1. táblázat tartalmazza.

A minta összetétele (Composition of the Sample)

\begin{tabular}{cccccc}
\hline & & \multicolumn{2}{c}{ Életkor (Age) } & Összesen (All) \\
\cline { 3 - 6 } & & $18-25$ & $26-33$ & $34-30$ & 198 \\
\hline \multirow{2}{*}{ Nem (Gender) } & Férfi (Male) & 145 & 7 & 46 & 445 \\
\cline { 2 - 5 } & Nö (Female) & 295 & 46 & 114 & 643 \\
\hline \multicolumn{2}{c}{ Összesen (All) } & 440 & 43 & 160 & \\
\hline
\end{tabular}

Forrás (Source): Saját szerkesztés (Authors'own compilation)

A megkérdezettek 82,5\%-a volt valamilyen gyakorisággal borfogyasztó, ezen belül a nők valamivel nagyobb arányban $84,2 \%$ ban mondták magukat annak, mint a férfiak (78,4\%). A vizsgált korcsoportokon belül gyakorlatilag nem volt eltérés a borfogyasztóknak az egyes csoportokon belüli arányában. A kérdezés során kitértünk az általános borfogyasztási szokásokra, (fogyasztás gyakorisága, helye fizetési hajlandóság, a vásárlás során a választást segítő döntési szempontok), vizsgáltuk a borfogyasztás és az alkoholizmus kapcsolatát, a borfogyasztás egészségre gyakorolt hatását, illetve az ezzel kapcsolatos véleményeket, valamint az alkoholmentesített, illetve csökkentett alkoholtartalmú borok ismertségét és az ezekkel a termékekkel kapcsolatos fogyasztói attitüdöket. Az eredményekből jelen tanulmányban a borfogyasztás és az alkoholizmus kapcsolatára vonatkozó attitűdök, valamint ezen újnak számító termékeknek az ismertségére és a kipróbálására vonatkozó adatok kerülnek közlésre. Az itt közöltekkel kapcsolatban három feltételezésből indultunk ki: H1.: A csökkentett alkoholtartalmú, illetve alkoholmentesített borok hazai ismertsége alacsony, H2.: Az alkoholtartalom csökkentése a borok esetében kevéssé ösztönöz a kipróbálásra, H3.: A borok alkoholtartalmának a csökkentése pozitív hatással van a borok (vélt) egészségességére.

\section{Eredmények - Results}

Mint már a bevezetőben is utaltunk rá, az alkoholmentes sörök hazai széles körű piaci megje- lenése az 1990-es évek első felére tehető, ekkor jelentek meg az első külföldi alkoholmentes borok is. Az azóta eltelt közel 30 év alatt a kínálat elsősorban a sörmárka termékek széles körében bővült, és a legtöbb sörmárka már alkoholmentes változatát is kínálják, úgy nálunk, mint szerte a világban.

Felmérésünkben kitértünk ezek fogyasztására, és annak indokaira is. A válaszolók 43,6\%-a szokott alkoholmentes sört fogyasztani. Ezen belül a nők közel fele, a férfiaknak csak valamivel több, mint harmadára volt jellemző a fogyasztás, kor szerint vizsgálva inkább a fiatalabb generáció volt arányaiban elutasító, az Y generáció tagjai körében a termék fogyasztása meghaladta a 85\%-ot és ez az arány a kor növekedésével tovább emelkedett.

$\mathrm{Az}$ alkoholmentes sör fogyasztásának a leggyakoribb oka értelemszerúen az autóvezetés volt, ugyanakkor nemek szerint bontva a válaszokból megállapítható, hogy a vélt egészségesség a hölgyek esetében motivált erősebben a fogyasztásra. Kor szerint nézve a $\mathrm{Z}$ generáció tagjai között volt a legnagyobb az egészségességre vonatkozó utalások aránya, vagyis őket motiválta nagyobb mértékben az egészségesség, mint faktor ezen termékek fogyasztásánál, jóllehet itt is kétszeres volt azok aránya, akik a vezetés miatt választották a „o\%-os” söröket.

Ami az alkoholfogyasztással kapcsolatos attitűdöket illeti, lényeges különbség inkább a bort fogyasztók és a bort nem fogyasztók között mutatkozott. Az attitűdskálára adott válaszok esetében a TOP2-t vizsgálva jelentős különbség tapasztalható általában a bort fogyasztók és a bort nem fogyasztók csoportjában, ugyanakkor 
voltak olyan állítások, melyekben az egyetértés iránya azonos volt, csak az arányokban találtunk különbséget. Így például azzal az állítással, mely szerint a mérsékelt alkoholfogyasztás nem alkoholizmus, a bort fogyasztók 87,5\%-a egyetértett, de a bort nem fogyasztók közel kétharmada, 61,5\%-a is hasonlóan vélekedett. A rendszeres fogyasztás esetében már lényegesen kevesebben vélekedtek így, a borfogyasztóknak kevesebb, mint fele, 40,6\%-a, a nem fogyasztók esetében a TOP2 (teljesen, illetve nagyon egyetértek) már csak alig haladta meg a 20\%ot. Ugyanakkor a „negatív” TOP2, vagyis azok aránya, akik egyáltalán, vagy nagyon nem értettek egyet ezzel az állítással a bort nem fogyasztók körében $31 \%$, duplája volt a borfogyasztók esetében tapasztalt 15, 1\%-nak. Még kisebb volt mindkét csoport esetében a TOP2 arra az állításra vonatkozóan, melyek szerint az olcsó borok rendszeres fogyasztása nem alkoholizmus. A fogyasztók 13,2\%-a, az elutasítók 8,4 \%-a értett egyet nagyon vagy teljesen ezzel az állítással. Figyelemre méltó volt a teljes alkoholfogyasztás elutasításával kapcsolatos felvetésünkre adott válaszok megoszlása. Azzal az állítással, mely szerint mennyiségtől és italféleségtől függetlenül minden alkoholfogyasztás veszélyes, a bort fogyasztók ötöde, $21 \%$, a nem fogyasztóknak csak közel harmada értett egyet $31 \%$, ugyanakkor az egyet nem értők aránya a borivóknál 40,1\%, a bort nem fogyasztóknál $22,9 \%$ volt. Az ezzel ellentétes állítással, nevezetesen „A bor mérsékelt fogyasztása beilleszt- hető az egészséges étrendbe" a borfogyasztók háromnegyede, 74,9\%, a nem fogyasztók közel fele, $46,8 \%$ értett egyet.

Rátérve az alkoholmentesített, illetve a csökkentett alkoholtartalmú borokra, a 4. ábra alapján megállapítható, hogy 63,75\%-uk még nem hallott ilyen termékekről, és akik hallottak, azoknak is mindössze 21,6\%-a rendelkezett személyes tapasztalatokkal, vagyis kóstolta ezeket a termékeket.

A hazai fogyasztók, és ezen belül az érintett generációk körében, mint a 5. ábrából is látható, kevéssé ismertek ezek a termékek, ezáltal a H1 hipotézisünk igazolást nyert. A bolti megfigyelési adataink alapján ez egyáltalán nem meglepő. A megkérdezéssel párhuzamosan végzett bolti megfigyeléseink szerint a hazai üzletláncoknak csak a töredékében találkozhatunk alkoholmentesített, vagy csökkentett alkoholtartalmú borokkal, és a kínálat is viszonylag szűkös. A megfigyelt üzleteknek csak kevesebb, mint felében (14-ből hat üzletben), közülük a TESCO-ban és az Aldi-ban találtunk több fajtát, de ezekre a láncokra sem volt jellemző, hogy valamennyi üzletükben fellelhetők az általunk keresett borok. A többi megfigyelt üzletlánc közül a SPAR Magyarország, a Lidl, a COOP, és a Penny esetében egy-egy fajta volt csak található a polcokon, de az adott lánchoz tartozó nem mindegyik üzletben, vagyis a szükös kínálat is magyarázza, hogy nagyon alacsony ismertséggel bírnak ezek a termékek.

-Nő (Female) * Férfi (Male)

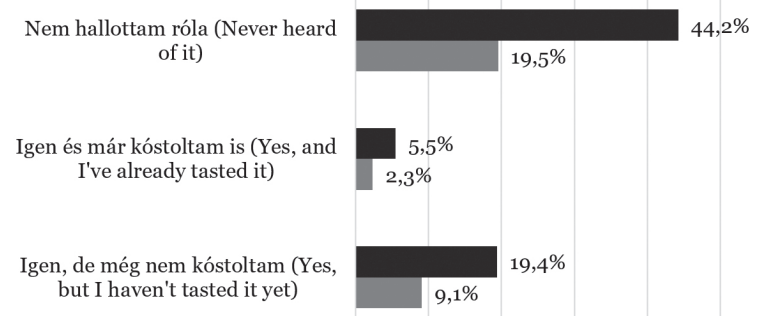

4. ÁBRA

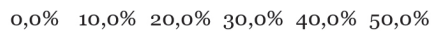

FIG. 4

A csökkentett alkoholtartalmú, illetve alkoholmentesített borok ismertsége a nemek tükrében (Awareness of Reduced-Alcohol and Non-Alcoholic Wines by Gender)

Forrás (Source): Saját szerkesztés (Authors'own compilation)

Megjegyzés (Notes): $\mathrm{n}=640$ 
Érdekes, hogy nemek szerint gyakorlatilag nem volt eltérés az ismertség tekintetében. Mind a férfiak, mind a nők hozzávetőleg egyharmada ismeri a vizsgált termékeket, és akik már kipróbálták azokat, szintén mind a höl- gyek, mind az urak vonatkozásában kevesebb, mint a megkérdezettek tizede.

A kutatásunk időszakában a 34-40 éves korosztály esetében volt valamivel magasabb az ismertség, amely az 5. ábrán látható.

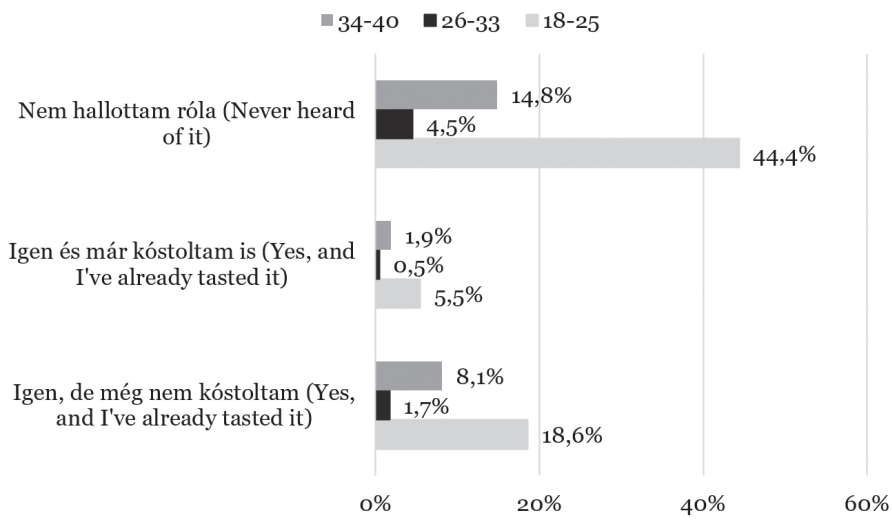

5. ÁBRA

$0 \%$

$20 \%$

$40 \%$

$60 \%$

FIG. 5

A csökkentett alkoholtartalmú, illetve alkoholmentesített borok ismertsége a különböző életkorúak véleménye alapján (Awareness of Reduced-Alcohol and Non-Alcoholic Wines Based on the Opinions of People of Different Ages)

Forrás (Source): Saját szerkesztés (Authors'own compilation)

Megjegyzés (Notes): $\mathrm{n}=640$

Végezetül arra kerestünk választ, hogy a minta tagjai vásárolnának-e alkoholmentesített, illetve csökkentett alkoholtartalmú bort. Az elutasítottság éppenhogy, de meghaladta az 50\%-ot, és viszonylag magas volt azok aránya is, több, mint 25\%, akik nem rendelkeznek kialakult véleménnyel a vásárlási szándékukat illetően. Vagyis elmondható, hogy mindössze a megkérdezettek valamivel kevesebb, mint negyede nyilatkozott vásárlási szándékáról, a H2 hipotézisünk is alátámasztást nyert.

Ezen belül, talán nem meglepő módon, de a férfiak arányaikat tekintve lényegesen elutasítóbbak voltak, mint a hölgyek. A generációk tekintetében az Y generáció vállalkozóbb kedvünek tekinthető a vásárlások szempontjából, mint az egészségtudatosabbnak tűnő $\mathrm{Z}$ generáció. Ugyanakkor a $\mathrm{H}_{3}$ hipotézist az eredmények alapján csak részben látjuk igazoltnak, az alkoholmentesített, illetve alkoholmentes borok esetében az egészségesség kevésbé befolyásolta a megkérdezetteket.
Végezetül vizsgáltuk, hogy azok, akik már kipróbálták a csökkentett alkoholtartalmú, illetve alkoholmentesített borokat, attitűdjeikben mennyire különböznek a hagyományos borfogyasztóktól. Jóllehet azok száma, akik kóstolták már ezeket a termékeket nem volt magas, a kapott válaszok mindenképpen jelzésértékűek a kutatás ezen szakaszában is. Amiben jelentôsen eltértek az előbb vizsgált fogyasztók és nem fogyasztók véleményétől, az egyrészt az olcsó borok és az alkoholizmus kapcsolata volt. Azzal az állítással, hogy az olcsó borok rendszeres fogyasztása nem alkoholizmus, 40\%-uk egyáltalán nem, 4\%-uk nagymértékben értett egyet, olyan nem volt, aki teljes mértékben osztotta volna ezt a megállapítást. Ugyanakkor azok aránya még a nem fogyasztóknál is alacsonyabb volt a túlzott borfogyasztás megítélésében, vagyis kisebb arányban értettek egyet nagyon, vagy teljesen abban, hogy a túlzott borfogyasztás alkoholizmusnak tekinthető. 


\section{KöVETKEZTETÉSEK -}

\section{CONCLUSIONS}

Vizsgálatunk megerősítette az eddigi ugyancsak nem reprezentatív felmérés eredményeit, nevezetesen ezek a termékek hazánkban még kevéssé ismertek, és az ismerők körében sem túlzottan kedveltek. Ugyanakkor a külföldi példák alapján vélelmezhető, hogy a közeljövőben mindinkább megjelennek ezek a borok a boltok pultjain, és a magyarországi jelenleg szűkös, és egyenetlen kínálat bővülni fog. A vizsgálat rámutatott, hogy a generációk között különbség van ezeknek a termékeknek az ismertségében.

A kutatás korlátai közül az alkoholmentesített és csökkent alkoholtartalmú borok általánosan alacsony ismertsége, a termékkörrel kapcsolatos kevés fogyasztói tapasztalat, valamint a reprezentativitás hiánya emelendő ki.

A külföldi tapasztalatok, a lakosság növekvő egészségtudatossága indokolttá teszi a kutatás folytatását. A feltáró kutatás alapján reprezentatív, nagymintás felmérés keretében kívánjuk folytatni vizsgálatunkat az Y és a Z generációnak az alkoholmentesített, illetve alkoholcsökkentett borokkal kapcsolatos attitűdjeik mélyebb megismerésére. Az attitűdök feltárásával lehetőség nyílik a vizsgált véleményeknek és az ismertségnek a marketingkommunikáció segítségével történő pozitív irányú megváltoztatására, illetve fogyasztói elfogadottságuk növelésére.

\section{6. ÖSSZEFOGLALÁS - SUMMARY}

Dolgozatunkban bemutattuk a csökkentett alkoholtartalmú, illetve az alkoholmentesített borok iránti kereslet alakulását, szekunder szakirodalom alapján felvázoltuk az alkoholfogyasztás lehetséges egészségügyi hatásait és egy feltáró kutatás keretében vizsgáltuk az Y és Z generáció fogyasztását ezeknek a hazánkban viszonylag újnak számító területen. A kutatás jelenlegi állásánál is megállapítható, hogy ezek a termékek kevésbé ismertek a hazai közönség körében, beleértve a vizsgált generációkat, de az egészségtudatosság növekedése - a külföldi példákhoz hasonlóan - elóbb-utóbb nálunk is érdekessé teszi ezeket a borokat. Érdemes tehát az említett generációknak nemcsak a ha- gyományos, de a csökkentett alkoholtartalmú és alkoholmentesített borokkal kapcsolatos attitűdjeiket, fogyasztói szokásukat elemezni, hogy a borágazat számára a későbbiekben releváns információkkal tudjunk szolgálni. Ehhez a kutatások kiterjesztésére, nagyobb mintáknak a kutatásba állítására és a külföldi ezirányú tapasztalatok folyamatos monitorozására van szükség.

\section{IRODALOMJEGYZÉK - REFERENCES}

Alcoholchange: Dry January. 2021. https:// alcoholchange.org.uk/get-involved/ campaigns/dry-january (Letöltés dátuma: 2021.08.26.)

Beckett, F.: Low-Alcohol Wine Is Not Wine, It's Grape Juice. Where's the Joy in That? 2017. https://www.theguardian. com/commentisfree/2017/nov/22/lowalcohol-wine-supermarkets-sales-drunk (Letöltés dátuma: 2020.11.15.)

Boshuizen, C.: Beauty Is in the Eye of the Beholder: A Study About the Effect of (A) Typical Package Design for Non-Alcoholic White Wine. 2020. http://essay.utwente. nl/80871/ (Letöltés dátuma: 2021.02.26.)

Breslow, R. A. - Chen, C. M. - Graubard, B. I. - Jacobovits, T. - Kant, A. K.: Diets of Drinkers on Drinking and Nondrinking Days: NHANES 20032008. The American Journal of Clinical Nutrition. 2013. 97 (5) 1068-1075. DOI: https://doi.org/10.3945/ajcn.112.050161

Bucher, T. - Deroover, K. - Stockley, C.: Low-Alcohol Wine: A Narrative Review on Consumer Perception and Behaviour. Beverages. 2018. 4 82. DOI: https://doi. org/10.3390/beverages4040082

Chiva-Blanch, G. - Urpi-Sarda M, Ros E. - Arranz, S. - Valderas-Martínez, P. - Casas, R. - Sacanella, E. Llorach, R. - Lamuela-Raventos, R. M. - Andres-Lacueva, C. - Estruch, R.: Dealcoholized Red Wine Decreases Systolic and Diastolic Blood Pressure and Increases Plasma Nitric Oxide: Short Communication. Circulation Research. 2012. 111 (8) 1065-1068. DOI: https://doi. org/10.1161/CIRCRESAHA.112.275636. 
Digital.nhs: Statistics on Alcohol. England, 2018.05.01. https://files.digital.nhs. uk/AD/C3036E/alc-eng-2018-rep.pdf (Letöltés dátuma: 2019.11.22.)

Drinkwre: UK alcohol unit guidance: $\mathrm{CMOs}^{\prime}$ Low Risk Drinking Guidelines. 2021. https://www.drinkaware.co.uk/alcoholfacts/alcoholic-drinks-units/latest-ukalcohol-unit-guidance/ (Letöltés dátuma: 2021.02.15.)

Freytag, V. B.: Wein ohne Rausch Zukunftsmarkt oder ewige Nische? 2019. https://www.faz.net/aktuell/wirtschaft/ unternehmen/hat-alkoholfreier-weinin-deutschland-potenzial-16231780.html (Letöltés dátuma: 2021.02.10.)

Gakidou, E.: Alcohol Use and Burden for 195 Countries and Territories, 1990-2016: A Systematic Analysis for the Global Burden of Disease Study 2016, Lancet. 2018. 392 1015-1035. DOI: http://dx.doi. org/10.1016/So140-6736(18)31310-2

GFK: Bor feltáró kutatás Tanulmány az FVM AMC megbízásából. A Nemzeti Borstratégia keretében Budapest. 2008

Halstead, R. - Abenathy, C.: Behind the Global SOLA Report: Sustainable,Organic and Lower Alcohol Wine Opportunities. $2018 . \quad$ https://www.wineintelligence. com/behind-the-global-sola-reportsustainable-organic-lower-alcohol-wineopportunities-2018/ (Letöltés dátuma: 2020.09.14.)

Haseeb, S. - Alexander, B. - Baranchuk, A.: Wine and Cardiovascular Health: A Comprehensive Review. Circulation. 2017. $136 \quad 1434-1448$. DOI: https://doi.org/10.1161/ CIRCULATIONAHA.117.030387

Hnt: Borászati termékek jelölési útmutatója. 2021. www.hnt.hu (Letöltés dátuma: 2021.02.04.)

Kádár, Gy.: Borászat. Mezőgazdasági Kiadó, Budapest, 1982

KSH: STADAT- 4.1.2.1.11. Bormérleg-1970-, Budapest, 2020. https://www.ksh.hu/ docs/hun/xstadat/xstadat_hosszu/elm11. html (Letöltés dátuma: 2021.02.25.)
Kunal, A. - Rawat, A.: Non-Alcoholic Wine and Beer Market Size By Product. 2019. https://www.gminsights.com/industryanalysis/non-alcoholic-wine-and-beermarket (Letöltés dátuma: 2020.10.15.)

Légrády, P.: Az alkohol- barát vagy ellenség? 2019. https://diabetes.hu/cikkek/ hypertonia/1802/az-alkohol-barat-vagyellenseg (Letöltés dátuma: 2020.09.11.)

Lamont, K. - Blackhurst, D. - Albertyn, Z. - Marais, D. - Lecour, S.: Lowering the Alcohol Content of Red Wine Does not Alter Its Cardioprotective Properties. South African Medical Journal. 2012. 102 (6) 565-567. DOI: https://doi. org/10.7196/samj.5733. PMID: 22668965.

Lugasi, A.: A vörösborok feltételezett preventív hatása. Komplementer Medicina. 2000. 4 (6) 10-14.

Magyar, I. - Petrányi, Gy.: A belgyógyászat alapvonalai, 1 kötet. Medicina Kiadó, 1974

Malhorta, N. K.: Marketingkutatás. Műszaki Kiadó, Budapest, 2001

Matos, L.: Melyik ital a hatásosabb vérnyomáscsökkentő? 2012. http:// medicalonline.hu / t u d o many / cikk/melyik_ital_a_hatasosabb_ vernyomascsokkento (Letöltés dátuma: 2021.10.12.)

Medicalonline: Idén is elstartol a Száraz November. 2019.10.31. http:// medicalonline.hu/kitekinto/cikk/iden is_elstartol_a_szaraz_november (Letöltés dátuma: 2021.08.26.)

Nagykálnai, T. - Landherr, L.: Alkohol és emlőrák. Rövid áttekintés. Magyar Onkológia. 2018. 62 68-71.

NJT: 2008. évi XLVI. törvény $\mathrm{Az}$ élelmiszerláncról és hatósági felügyeletéről, 2021. Hatályos: 2021.06.05-2021.12.31. https://njt.hu/ jogszabaly/2008-46-00-00.48 (Letöltés dátuma: 2021.08.26.)

OSZKÓ - FVM Szőlészeti és Borászati Kutatói Intézet: Borfogyasztási szokások Magyarországon Tanulmány, az FVM AMC megbízásából, 2003 
OTSZOnline: Alkoholfogyasztás és szívinfarktus. 2014. http://otszonline.hu/ cikk/alkoholfogyasztas_es_szivinfarktus (Letöltés dátuma: 2020.10.15.)

Pickering, G. J.: Low-and Reducedalcohol Wine: A Review. Journal of Wine Research. 2000. 11 129-144. https://doi. org/10.1080/09571260020001575

Rábai, M. - Tóth, A. - Sándor, B. Papp, J. - Kenyeres, P. - Márton, Zs. - Juricskay, I. - Czopf, L. Márk, L. - Herbert, J. - Tóth, K.: A vörösbor kedvező hemoreológia hatásai: experimentális humán klinikai vizsgálatok. Érbetegségek. 2017. 1 3-12. http://erbetegsegek.com/image/temak/ arteriak_betegsegei/69ment.pdf (Letöltés dátuma: 2020.12.10.)

Saliba, A. J. - Moran, C. C.: The Influence of Perceived Healthiness on Wine Consumption Patterns. Food Quality and Preference. 2010. 21 (7) 692-696. DOI: https://doi.org/10.1016/j. foodqual.2010.05.006

Saliba, A. J. - Ovington, L. A. - Moran, C. C.: Consumer Demand for LowAlcohol Wine in an Australian Sample. International Journal of Wine Research. 2013.51-8. DOI: https://doi.org/10.2147/ IJWR.S41448

Schultz, E. J.: Alcohol Markets Face Sobering Times as Moderation Trend Grows. 2019. https://adage.com/article/cmo-strategy/ alcohol-makers-face-sobering-timesmoderation-trend-grows/316310 (Letöltés dátuma: 2020.11.28.)

Sidlovits, D.: Mit szól a világ a borhoz, ha nincs benne (elég) alkohol? Borászati füzetek. 2019. 2 21-24. https:// magyarmezogazdasag.hu/2019/07/26/ mit-szol-vilag-borhoz-ha-nincsbenne-eleg-alkohol (Letöltés dátuma: 2020.05.15.)

Szolnoki, G. - Totth, G.: A magyar borszektor elemzése piaci és fogyasztói szempontból. Borászati füzetek. 2018. 28 (1, melléklet) 1-30.
Takács, L.: A membránszeparáció szerepe borok alkoholcsökkentésében és ipari alkoholok dehidratációjában. Corvinus Egyetem Élelmiszertudományi Kar, Budapest, 2010

Totth, G. - Szolnoki, G.: A magyarországi borfogyasztói szokások és a borpiac elemzése. Gazdálkodás. 2019. 63 (1) 2239.

Trade Magazin: www.trademagazin.hu, 2012.03.09. (Letöltés dátuma 2021.01.12.)

Turcsán, J. - Régi, Zs. - Illyés-Kovács, A.: Magyar felnőtt lakosok alkoholmentesített italok fogyasztási szokásai, III. Zalaegerszegi Egészségturizmus Konferencia Tanulmánykötet. 2020. 158168.

Turizmus Bulletin: Bormarketing munkát támogató piackutatás a magyar borpiacon. Kutatási jelentés. 2013. 15 (1) 50-56. https://mtu.gov.hu/documents/ prod/ATTo0176.pdf (Letöltés dátuma: 2021.02.20.)

Vasiljevic, M. - Couturier, D. L. Marteau, T. M.: Impact on Product Appeal of Labeling Wine and Beer with (A) Lower Strength Alcohol Verbal Descriptors and (B) Percent Alcohol by Volume (\% ABV): An Experimental Study. Psychology of Addictive Behaviors. 2018 32 (7) 779-791. DOI: https://doi.org/10.1037/ adboooo376

Vasiljevic, M. - Couturier, D. L. Frings, D. - Moss, A. C. - Albery, I. P. - Marteau, T. M.: Impact of Lower Strength Alcohol Labeling on Consumption: A Randomized Controlled Trial. Health Psychology. 2018 37 (7) 658-667. DOI: https://doi.org/10.1037/ heaoooo622

WHO: Global Status Report on Alcohol and Health 2014. Genf. https:// apps.who.int/iris/bitstream/handle /10665/112736/ 112736/9789240692763 _eng.pdf;jsessionid $=14056 \mathrm{Co} 72509 \mathrm{DE} 3$ C82DA 01DB38127F6D ?sequence $=1$ (Letöltés dátuma: 2020.05.25.) 


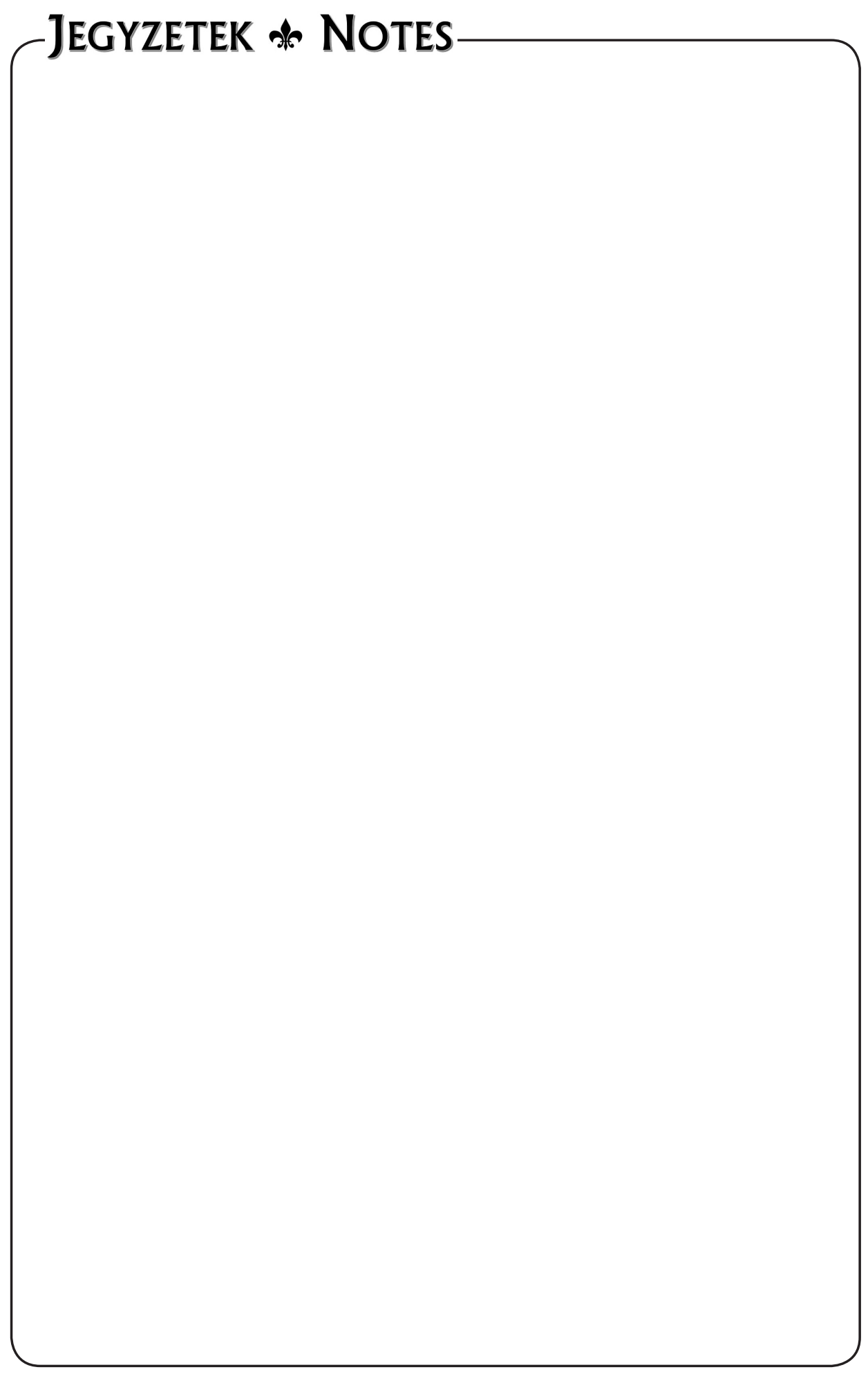

